\title{
CHEILOLEJEUNEA OBTUSIFOLIA (LEJEUNEACEAE) NEW TO THE INDIAN MAINLAND FROM THE WESTERN GHATS
}

\author{
R. Sreebha, K. C. Kariyappa and A. E. D. Daniels* \\ Bryology Laboratory, Department of Botany and Research Centre \\ Scott Christian College, Nagercoil-629 003, Tamil Nadu, India \\ *E-mail:dulipdaniels@yahoo.co.uk
}

(Received 17 July, 2015; Accepted 5 December, 2015)

\begin{abstract}
Cheilolejeunea obtusifolia, so far known only from Andaman Islands in India, is added here to the flora of the Indian mainland from the Anamalais in the Western Ghats. A brief description with an illustration and a photoplate is provided here since there is none based on any Indian material.
\end{abstract}

Key words: Anamalais, Cheilolejeunea obtusifolia, Western Ghats

\section{INTRODUCTION}

Cheilolejeunea obtusifolia (Steph.) S. Hatt., reportedly endemic to Japan, was first discovered outside Japan by Joshi et al. (1992) in Andaman Islands in India. Unfortunately, they did not provide a description or illustration in their publication and all subsequent authors (Chavan 2010, Deo and Singh 2013, Joshi 2001) included this species only in checklists for regions of India based on Joshi et al.'s (1992) report.

In the course of collecting bryophytes for a proposed bryoflora of Anamalais in the Western Ghats, the hitherto mentioned species was discovered, which is a new record for the Indian mainland. A brief description with an illustration and a photoplate is provided here since there is none based on any Indian material.

\section{Cheilolejeunea obtusifolia (Steph.) S. Hatt., Misc. Bryol. Lichénol. 1: 1 (1957)}

(Figs 1-23)

Mizut., J. Hattori Bot. Lab. 24: 197, fig. XVIII (1-8) (1961) \& 51: 159, fig. 4 (1982); Joshi, D. Y. et al., Bryobrothera 1: 130 (1992); So, M. L. and Zhu, R.-L., Bot. Bull. Acad. Sin. 37: 277, fig. 2 (1996); Zhu, R.-L. et al., Nova Hedwigia, Beih. 75: 400 (2002). 
Basionym: Harpalejeunea obtusifolia Steph., Sp. Hepat. 5: 265 (1913) 三Euosmolejeunea obtusifolia (Steph.) S. Hatt., J. Hattori Bot. Lab. 5: 85 (1951). - Type: Japan, Kagoshima Pref., Yakushima Is., July 1900, Coll.: U. Faurie 879 (G).

= Strepsilejeunea pusilla S. Hatt., Bull. Tokyo Sci. Mus. 11: 136 (1944). - Type: Japan, Kagoshima Pref., Mt Takakuma, April 1939, Coll.: S. Hattori 1631 (TNS).

= Pycnolejeunea obtusifolia S. Hatt., Hattori Bot. Lab. 3: 44 (1950). - Type: Japan, Nichinan, Miyazaki Pref., on branches of trees and shrubs in lowlands in southernmost Japan, ca 30 m, October 16, 1945, Coll.: S. Hattori 12053 (NICH).

Plants 2-8 mm long, olive-green to pale brown. Stems prostrate, ca 0.06 $\times 0.04 \mathrm{~mm}$ in cross section, ca 4-celled across; cortex 8-celled, with 10-16 $\times$ 8-14 $\mu \mathrm{m}$ thick walled cells enclosing $c a$ 4, smaller, 8-10 × 6-8 $\mu \mathrm{m}$ thick walled medullary cells; ventral merophytes 2 or 3 cells wide. Leaves imbricate to approximate, squarrose, obliquely spreading, $0.24-0.32 \times 0.14-0.16 \mathrm{~mm}$, obliquely ovate, arched at antical margin, entire, obtuse at apex; apical cells 8-12 $\times$ 6-8 $\mu \mathrm{m}$, with faint trigones and intermediate thickenings; median ones 10-16 $\times 10-14 \mu \mathrm{m}$, with faint to large trigones and intermediate thickenings; basal ones 16-24 × 12-16 $\mu \mathrm{m}$, with large, distinct trigones and few intermediate nodular thickenings; cuticle smooth; oil bodies 2 or 3 per cell, ovoid to fusiform, faintly granular-segmented; lobules $0.14-0.16 \times 0.08-0.09 \mathrm{~mm}, 1 / 2$ to 3/5 as long as lobe, obliquely ovate, swollen, constricted and ring-like at apex, with an inconspicuous first tooth and a distinct, 3-5 times as long as wide, 1-celled second tooth with a hyaline papilla at its base; keel arched, with an acute sinus at apex, crenulate. Underleaves distant, obliquely to sinuately inserted, 2-3 times as broad as stem, 0.8-1 $\times 0.6-0.8 \mathrm{~mm}$, orbicular to ovate, 2-lobed for 1/3-1/2, entire. Sex organs and sporogonium not seen. $1,140 \mathrm{~m}$.

Habitat: Corticolous on Acacia sp. (Mimosaceae) in mixed plantations, $c a$

Distribution: China, Japan, Micronesia and India: Andaman Islands and Western Ghats of Tamil Nadu.

Specimens examined: Western Ghats, Tamil Nadu, Coimbatore Dist., Anamalais, Valparai, mixed plantation. Alt.: ca 1,140 m a.s.1., 18.02.2013, Coll.: A. E. D. Daniels and K. C. Kariyappa (9142 p.p.). Alt.: ca 1,300 m a.s.l., 04.02.2015, Coll.: R. Sreebha and K. C. Kariyappa (9879 p.p.) (SCCN).

Figs 1-10. Cheilolejeunea obtusifolia (Steph.) S. Hatt. $-1=$ portion of plant; $2=$ cross section of stem; $3=$ leaves; $4=$ apex of leaf lobule; $5=$ leaf apical cells; $6=$ leaf median cells with oil bodies; 7-8 = leaf median cells; 9 = leaf basal cells; $10=$ underleaves (drawn from Daniels, A. E. D. and Kariyappa, K. C., 9142 p.p.) 

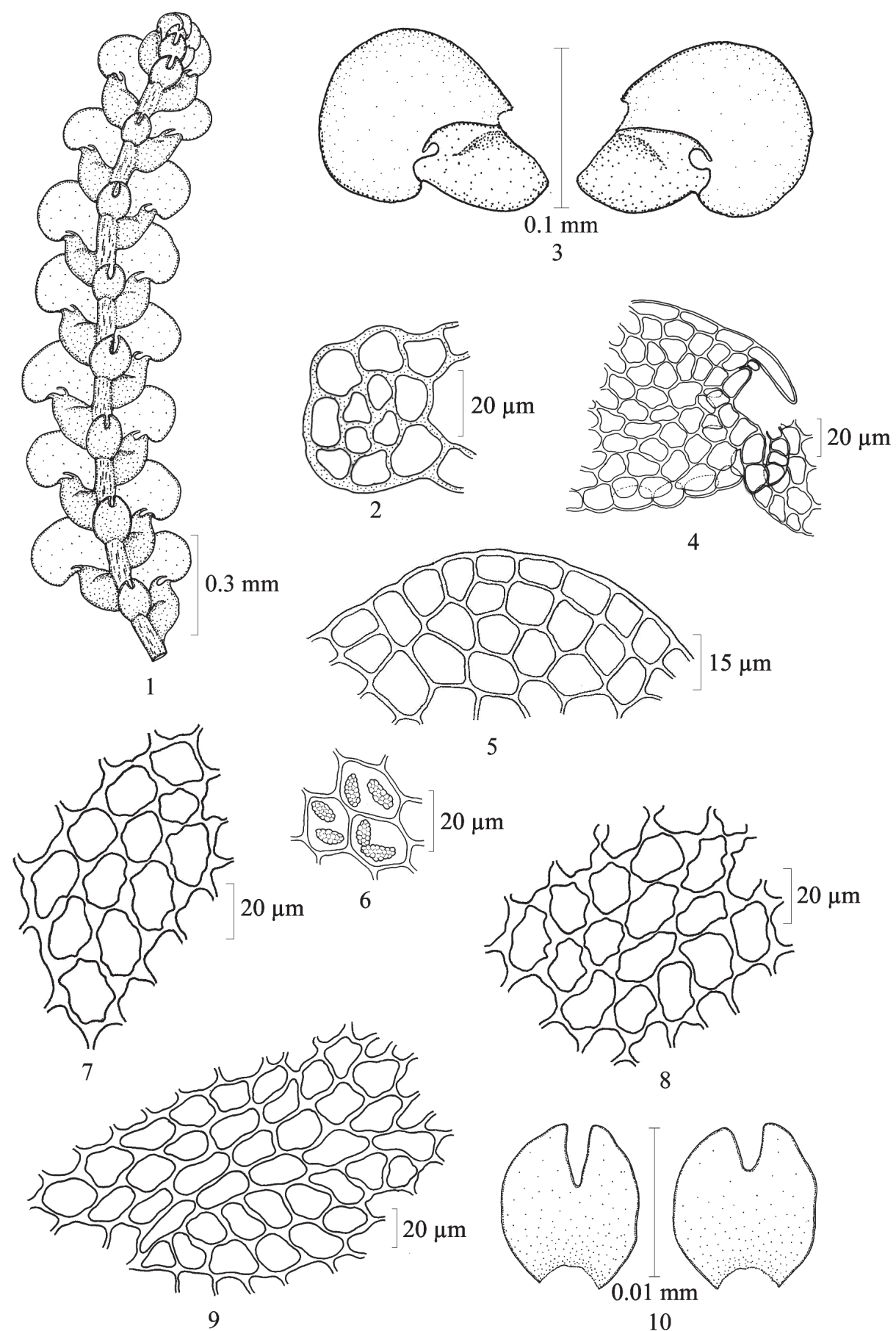

5
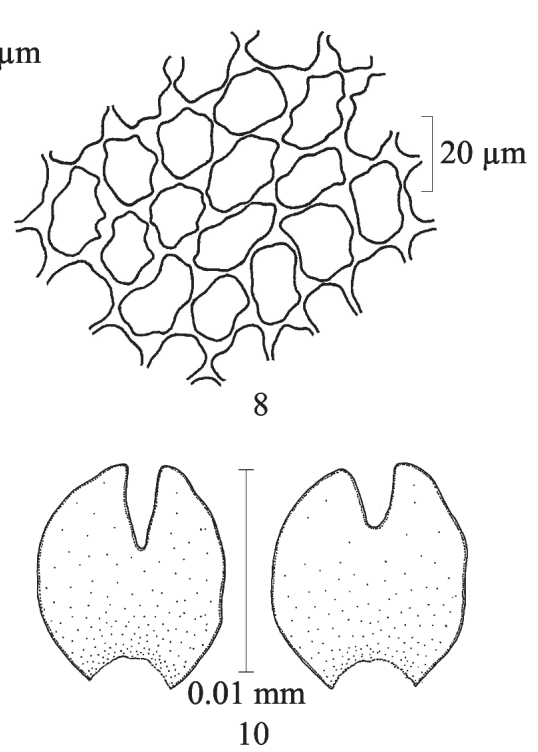

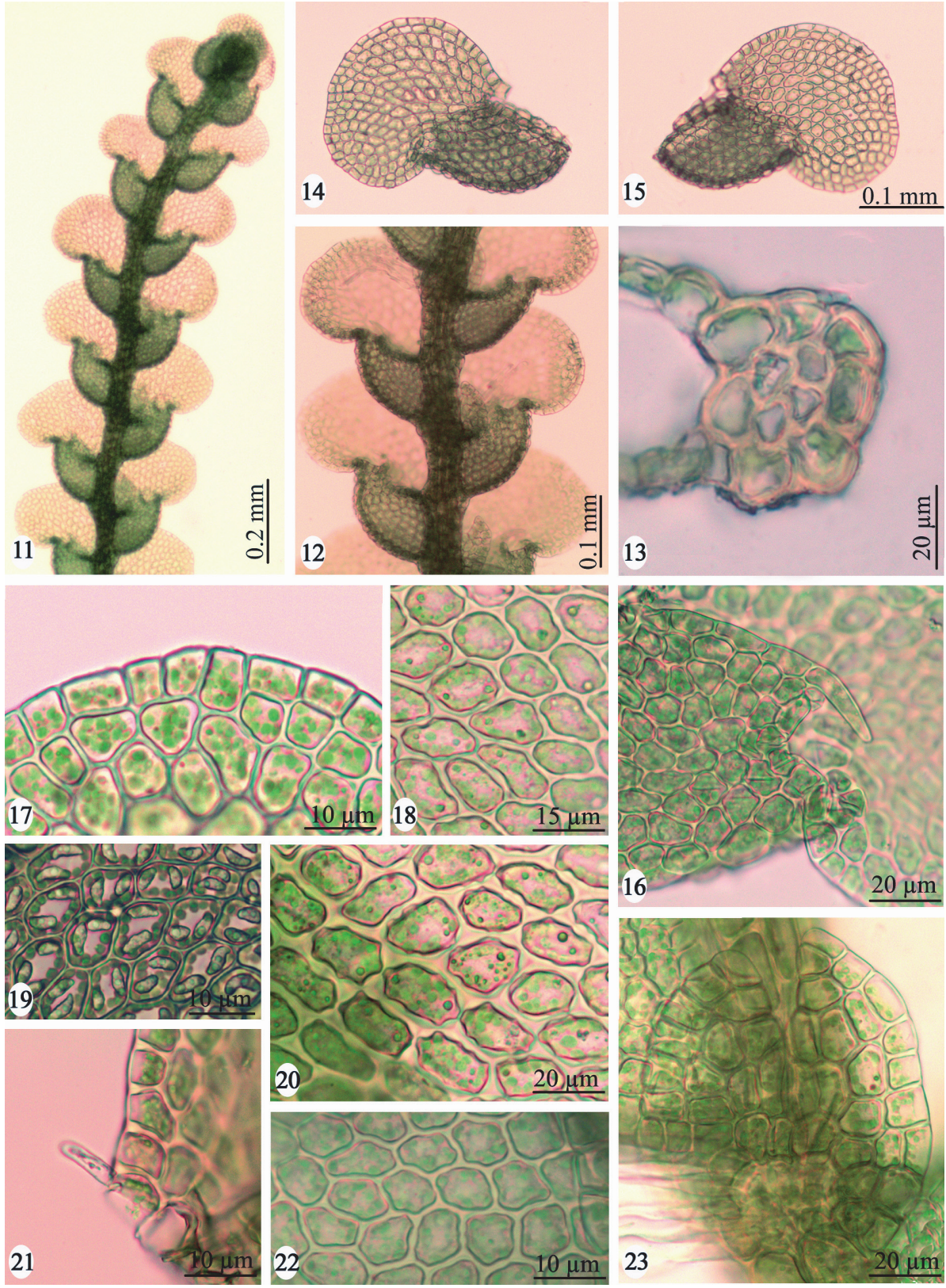

Figs 11-23. Cheilolejeunea obtusifolia (Steph.) S. Hatt. $-11=$ portion of plant; $12=$ a portion enlarged; 13 = cross section of stem; $14-15=$ leaves; 16 = apex of leaf lobule; 17 = leaf apical cells; 18 = leaf median cells; $19=$ leaf median cells with oil bodies; 20 = leaf basal cells; 21 = hyaline papilla on dorsal side at leaf base; 22 = leaf lobule cells; 23 = underleaf (photographed from Daniels, A. E. D. and Kariyappa, K. C., 9142 p.p.) 
Acknowledgements - We thank the Tamil Nadu State Forest Department for permission to explore the study area. AEDD thanks the Department of Science and Technology (DST), New Delhi, India for financial assistance, D. K. Singh (CAL) and G. Winter (Senckenberg Natural History Museum, Germany), for help with literature and M. J. Wigginton (Peterborough, United Kingdom), for help with literature and comments, and the Principal, Scott Christian College, Tamil Nadu, India for facilities.

\section{REFERENCES}

Chavan, S. J. (2010): Studies on the family Lejeuneaceae from Andaman Islands, India. Bioinfolet 7: 4-8.

Deo, S. S. and Singh, D. K. (2013): Cheilolejeunea eximia (Lejeuneaceae: Marchantiophyta) - an addition to the Indian bryoflora from Eastern Himalaya with a note on distribution of the genus in India. - NeBio 4: 52-57.

Hattori, S. (1944): Contributio ad Floram Hepaticarum Austro-Kiushiuensem. - Bull. Tokyo Sci. Mus. 11: 1-203.

Hattori, S. (1950): Hepaticarum species novae et minus cognitae Nipponenses. 6. - J. Hattori Bot. Lab. 3: 37-52.

Hattori, S. (1951): Oil bodies of Japanese Hepaticae. - J. Hattori Bot. Lab. 5: 69-97.

Hattori, S. (1957): A short review of some genera of Japanese Lejeuneaceae. - Misc. Bryol. Lichénol. 1: 1-2.

Mizutani, M. (1961): A revision of Japanese Lejeuneaceae. - J. Hattori Bot. Lab. 24: 115-302.

Mizutani, M. (1982): Notes on the Lejeuneaceae. 6. Japanese species of the genus Cheilolejeunea. - J. Hattori Bot. Lab. 51: 151-173.

Joshi, D. Y. (2001): A floristic analysis of the liverworts from Andaman Islands, India. - In: Nath, V. and Asthana, A. K. (eds): Perspectives in Indian Bryology. Bishen Singh Mahendra Pal Singh, Dehradun, pp. 135-148.

Joshi, D. Y., Wani, D. D. and Chavan, S. J. (1992): Liverwort flora from the tropical rain forests of Andaman Islands, India. - Bryobrothera 1: 127-132.

So, M. L. and Zhu, R.-L. (1996): Two newly recorded species of the genus Cheilolejeunea (Lejeuneaceae, Hepaticae) in Hong Kong and China. - Bot. Bull. Acad. Sin. 37: 275-280.

Stephani, F. (1912-1917): Species Hepaticarum. Vol. 5. - George \& Cie, Lyon.

Zhu, R.-L., So, M. L. and Wang, Y.-F. (2002): The genus Cheilolejeunea (Hepaticae, Lejeuneaceae) in China. - Nova Hedwigia 75: 387-408. http://dx.doi.org/10.1127/00295035/2002/0075-0387 